\title{
Impact of shading on selected developmental, physiological and chemical parameters of southern sweet-grass (Hierochlö̈ australis (Schrad.) Roem. et Schult.)
}

\author{
K. Bączek, J.L. Przybył, O. Kosakowska and Z. Węglarz
}

Laboratory of New Herbal Products, Department of Vegetable and Medicinal Plants, Faculty of Horticulture, Biotechnology and Landscape Architecture, Warsaw University of Life Sciences - SGGW, Warsaw, Poland

\begin{abstract}
Summary
Southern sweet-grass is a tuft grass growing in coniferous and mixed forests of Eastern Europe. Its leaves, collected only from the wild, has been used for the aromatization of alcohol and tobacco products. Due to extensive collection of raw material, the species is threatened with extinction. Thus, introduction into cultivation gives the chance for its survival in natural habitat. The aim of the study was to assess in ex situ conditions the influence of shading on southern sweetgrass development and accumulation of biologically active compounds. The objects of the study were two-year-old plants, grown under $0 \%$ (full sunlight), $35 \%$ and $50 \%$ shading, provided by shading nets. The highest number of fertile shoots was obtained at $35 \%$ shading, however the highest mass of seeds per plant as well as the highest 1,000 -seed weight was observed at $50 \%$ shading. The leaves were harvested twice, i.e., in June ( $1^{\text {st }}$ cut) and in September ( $2^{\text {nd }}$ cut, regrowth). The highest cumulative weight of leaves (from two cuts) was obtained at $35 \%$ shade $\left(33.63\right.$ g plant $^{-1}$ DM). In both cuts the content of coumarin (detected by HPLC-DAD), responsible for the industrial quality of raw material, was distinctly higher in the leaves of plants grown at $50 \%$ and $35 \%$ shading compared to those from full sunlight. Such relation was also observed concerning the content of chlorophyll $a$ and $b$. The obtained results show that shade should be provided in southern sweet-grass cultivation to obtain high and good quality yield of leaves.
\end{abstract}

Keywords

chlorophyll $a+b$, coumarin, leaves quality, light intensity, phenolic acids, seeds

\section{Introduction}

Southern sweet-grass (Hierochloë australis (Schrad.) Roem. et Schult.; Poaceae), commonly known as a bison grass, is a tuft grass growing wild almost exclusively in Poland, Latvia, Lithuania, Belarus and Finland. In Poland, since 1983 it has had a status of partially protected plant. It has also been included into the Red List of Plants and Fungi in Poland, in a group of plants exposed to extinction (Gawłowska et al., 1989; Radusciene, 2002; Mirek et al., 2006).

It usually grows at the edges of mixed forests or on forest's fellings as one of undergrowth species (Ćwikliński and Głowacki, 1990). The raw material collected from this plant

\section{Significance of this study}

What is already known on this subject?

- Southern sweet-grass grows naturally in coniferous or mixed forest. Thus shade seems to be a natural environmental element of its habitat. The preliminary study suggests that shade influences the accumulation of biologically active compounds in its leaves.

\section{What are the new findings?}

- Shade influences southern sweet-grass yielding parameters (number, length and width of leaves) as well as its developmental traits, i.e., the number of fertile shoots per plant, their height, the mass of seeds (spikelet) per plant and 1,000-seed weight. The contents of chlorophyll $a$ and $b$, phenolic acids, and coumarin in the leaves strictly depend on the shade level, as well.

What is the expected impact on horticulture?

- In cultivation, southern sweet-grass produces relatively high yield of leaves. Its weight and quality may be regulated using different shading levels. Cultivation of such wild growing species, providing important industrial raw materials, is the best way to protect the plants in natural habitat. It is also an interesting alternative for small farms to obtain a crop of relatively high value.

are leaves, rich in coumarin with coumarin as a dominant compound. Coumarin is responsible for sweet aroma of the raw material (Lake, 1999). The leaves are mainly used for the production of extracts applied for aromatization of alcoholic products, especially vodka manufactured traditionally in Poland, called 'Bison grass vodka'. The raw material is also utilised in tobacco industry and as a food additive. High demand for the raw material results in excessive collection of the leaves, which makes the plant threatened with extinction (Gawłowska et al., 1989). Therefore, it seems that the best method to preserve the species in the nature is to introduce it into cultivation.

One of the most important factors influencing the growth of this plant seems to be light intensity. In the wild, the generative growth of southern sweet-grass follows at the early spring, when the plants are not shaded, since broadleaf trees upon which it grows are still leafless. Only after seed setting, the plant begins vegetative growth with intensive production of dark-green leaves covered, on their upper side, with white 
powdery coating rich in coumarin compounds (Przybył et al., 2011). Thus, the vegetative growth takes place in a shadow provided by canopy trees. Such type of plant development is typical for many undergrowth species of a leafy and mixed forest in Central Europe, i.e., Allium ursinum L., Asarum europaeum L., Asperula odorata L., Pulmonaria officinalis L. and Pulmonaria obscura L.

The preliminary trials on southern sweet-grass cultivation indicate that the quality of raw materials is related with intraspecific diversity of the plant, term of harvest, the age of plants as well as fertilizer application (Wierzchowska-Renke, 1993; Węglarz et al., 2004; Przybył et al., 2011; Bączek et al., $2014,2015)$. However, there is little information on the factors influencing its development. The aim of the study was to determine, under controlled cultivation, the effect of plant shading on selected physiological, developmental and chemical traits of southern sweet-grass with special emphasis on the accumulation of coumarin in the leaves. Since the species grows naturally in forest, it seems that shade is one of the most important factors influencing its development and the quality of raw material. Explanation of such relationship is very important in terms of the possibility of introducing the plant into cultivation.

\section{Materials and methods}

\section{Plant material}

Southern sweet-grass maternal plants, used in this experiment, originated from seeds of a wild growing population, collected in the Eastern Poland (mixed forest, $52^{\circ} 37.944^{\prime} \mathrm{N}$; $22^{\circ} 45.718^{\prime} \mathrm{E}$ ). The field experiment was conducted at the Experimental Station of the Department of Vegetable and Medicinal Plants, WULS-SGGW, in two cycles, in 2013-2014 and 2014-2015. Meteorological data are presented in Table 1. The experiment was established by using 4-stem cuttings obtained by division of 3-year-old maternal plants (tufts), which represented one clone selected from among above mentioned population, maintained in the collection of Medicinal and Aromatic Plants of Warsaw University of Life Sciences - WULS (Bączek et al., 2012).

Stem cuttings were taken from maternal plants in autumn and planted in a greenhouse in multi-cell trays filled with peat substrate of $\mathrm{pH}$ 6.0. Well-rooted cuttings were planted out in the field at the end of June on the medium heavy alluvial soil amended with peat of $\mathrm{pH}_{(\mathrm{KCl})} 6.4$ and river sand. Nitrogen $\left(\mathrm{NH}_{3}-50 \mathrm{~kg} \mathrm{ha}^{-1}\right)$, phosphorus $\left(\mathrm{P}_{2} \mathrm{O}_{5}, 50 \mathrm{~kg} \mathrm{ha}^{-1}\right)$ and potassium fertilization $\left(\mathrm{K}_{2} \mathrm{O}, 80 \mathrm{~kg} \mathrm{ha}^{-1}\right)$ were applied before planting.

The plants were cultivated in full sunlight and at $35 \%$ and $50 \%$ shading, provided by shading nets. Plants were planted out in a spacing $50 \times 30 \mathrm{~cm}$. The experiment was established in three replications, in the randomized block design. On a single plot 35 cuttings were planted. The drip irrigation sys-
TABLE 1. Meteorological data.

\begin{tabular}{lrcr}
\hline & \multicolumn{3}{c}{ Year } \\
\cline { 2 - 4 } Month & 2013 & 2014 & 2015 \\
\cline { 2 - 4 } April & \multicolumn{3}{c}{ Mean temperature $\left({ }^{\circ} \mathrm{C}\right)$} \\
May & 16.2 & 11.2 & 9.2 \\
June & 19.6 & 15.0 & 14.0 \\
July & 21.0 & 17.3 & 18.6 \\
August & 22.2 & 18.8 & 20.6 \\
September & 12.8 & 15.3 & 23.4 \\
October & 10.7 & 9.9 & 16.1 \\
\hline & \multicolumn{3}{c}{ Precipitation $(\mathrm{mm})$} \\
\hline April & 52.1 & 44.6 & 19.9 \\
May & 122.1 & 68.7 & 38.4 \\
June & 96.8 & 84.1 & 20.1 \\
July & 18.6 & 87.8 & 50.6 \\
August & 72.1 & 74.7 & 4.4 \\
September & 87.3 & 12.1 & 43.2 \\
October & 25.4 & 9.2 & 37.7 \\
\hline
\end{tabular}

tem was applied. All observations were made in the second year of plant vegetation.

Voucher specimens were deposited at the herbarium of the Department of Vegetable and Medicinal Plants WULSSGGW.

\section{Measurement of solar radiation intensity}

The measurement of intensity of photosynthetic active irradiation was done using a phytophotometer (RF-100, Sonopan) just before first and second cut, $40 \mathrm{~cm}$ above ground level, in five replications on each plot. The results presented are mean values (Table 2).

\section{Measurement of developmental traits}

Developmental traits were observed in mid-June, at the stage of full ripening of seeds (spikelet). The following plant parameters were described: number of fertile shoots, their height, mass of seeds per plant, 1,000 seed weight (according to ISTA, 2014). The observations were made on ten plants randomly selected from each plot and presented results are mean values.

\section{Measurement of morphological traits}

All the measurements of the leaves were made twice during vegetation: at mid-June ( $1^{\text {st }}$ cut) and at mid-September ( $2^{\text {nd }}$ cut, regrowth). The plants were compared in terms of leaf number, length and width. The measurements were made on ten plants randomly selected from each plot and presented as mean values.

TABLE 2. The intensity of photosynthetic active irradiation (PAR; $\mu \mathrm{mol}$ photons $\mathrm{m}^{-2} \mathrm{~s}^{-1}$ ) under different light treatments (mean values).

\begin{tabular}{llrcr}
\hline & Assessment dates & \multicolumn{3}{c}{ Shade level } \\
\cline { 3 - 5 } & & $0 \%$ & $35 \%$ & $50 \%$ \\
\hline \multirow{3}{*}{ Full sunlight } & Mid-June & 2510 & 1710 & 750 \\
& Mid-September & 2210 & 1490 & 650 \\
\cline { 2 - 5 } Cloudy sky & Mid-June & 920 & 540 & 380 \\
& Mid-September & 660 & 390 & 130 \\
\hline
\end{tabular}




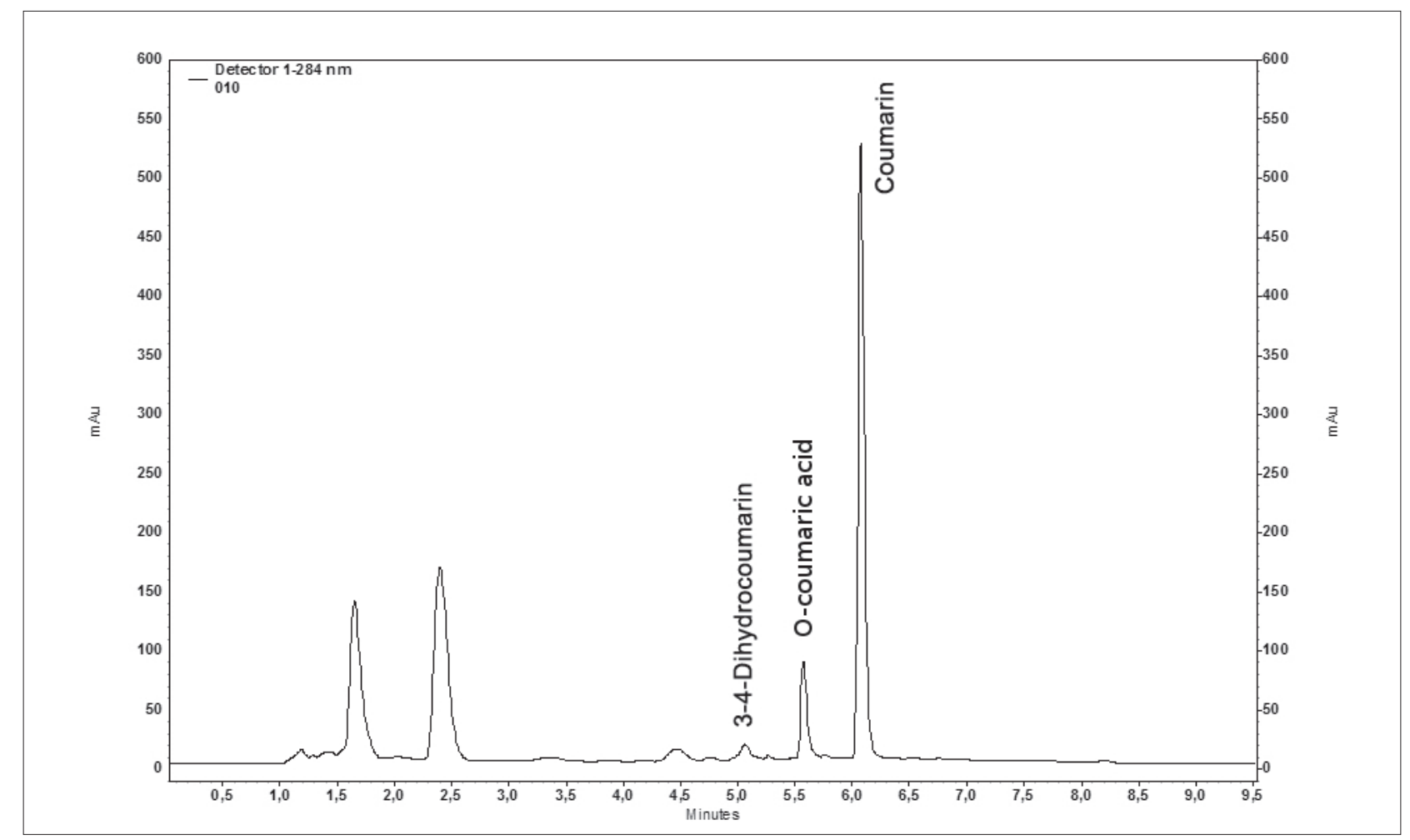

FIGURE 1. The HPLC chromatogram of coumarin compounds separation.

\section{Harvest}

The plants from each plot were harvested two times. They were cut $5 \mathrm{~cm}$ above ground level to preserve their tillering nodes from injury. Air-dry weight was calculated in $g$ per plant. After harvesting leaves were dried at a temperature of $40^{\circ} \mathrm{C}$, powdered and subjected to chemical analysis. The analysis was performed in three replications on raw materials collected separately from each plot. The presented results are mean values from replications.

\section{Determination of chlorophyll $\boldsymbol{a}$ and $\boldsymbol{b}$ content}

Content of chlorophyll $a$ and $b$ of air-dry raw material was determined according to Lichtenthaler and Wellburn (1983).

\section{Determination of total phenolic acids content}

Total content of phenolic acids (expressed as caffeic acid equivalents, \%) was determined spectrophotometrically, according to Polish Pharmacopoeia VIII (2008).

\section{Determination of coumarin compounds content}

1. Method validation. Commercially available standards (ChromaDex ${ }^{\circledR}$, Irvine, USA) were separately dissolved with methanol (Sigma-Aldrich, Poznań, Poland) in 10-mL volumetric flask according to the ChromaDex's Tech Tip 0003 Reference Standard Recovery and Dilution and used as standard stock solutions (ChromaDex's Tech Tip 0003). Further calibration levels were prepared by diluting 10, 50, 100, 200, 500 and $1,000 \mu \mathrm{L}$ of these solutions with methanol in $10-\mathrm{mL}$ volumetric flasks. The working solutions were injected $(1 \mu \mathrm{L})$ on a column in six replications $(n=6)$ using SIL-20A to generate a six-point calibration curve for each standard compound separately. Method parameters were calculated with Microsoft Excel 14 (Table 2). Signal-to-noise ratio approach were used to determined limit of detection LOD (S/N of 3:1) and limit of quantitation LOQ (S/N of 10:1).

2. Sample preparation. Air-dry, finely powdered and ho- mogenized raw material ( $1.0 \mathrm{~g}$ of leaves) was extracted with $100 \mathrm{~mL}$ of methanol in Büchi Labortechnik AG Extraction System B-811. Soxhlet hot extraction with twenty-five extraction cycles, flushing and drying was used. After evaporation of solvent, the residue was dissolved in $10 \mathrm{~mL}$ of methanol. The obtained extracts were filtered with Supelco IsoDisc $^{\mathrm{TM}}$ Syringe Tip Filter Unit, PTFE membrane, diameter $25 \mathrm{~mm}$, pore size $0.20 \mu \mathrm{m}$.

3. Parameters of separations. The separations were performed at C18 reversed-phase column Phenomenex Kinetex $^{\circledR} 2.6 \mu \mathrm{m}, 100 \times 4.60 \mathrm{~mm}$ (Phenomenex ${ }^{\circledR}$, USA) using a Shimadzu chromatograph equipped with auto sampler SIL-20A, photodiode array detector SPD-M10A VP PDA and CLASS $V^{\text {VM }} 7.3$ chromatography software (Shimadzu, Kyoto, Japan). Binary gradient of deionised water adjusted to $\mathrm{pH} 3$ with phosphoric acid (A) and ACN (B) was used as follows: 0 min $17 \%$ B; 0.5 min - 17\% B; 2.0 min - 50\% B; 2.5 min - 50\% B; $2.51 \mathrm{~min}-17 \% \mathrm{~B} ; 10.00 \mathrm{~min}-\mathrm{STOP}$, flow rate $1.1 \mathrm{~mL} \mathrm{~min}^{-1}$, oven temperature $35^{\circ} \mathrm{C}$, injection volume $1 \mu \mathrm{L}$.

4. Parameters of data integration. Peak identification was confirmed by comparison of retention time and UV-spectra with adequate parameters of standards. Detection wave applied: $273 \mathrm{~nm}$ for 3,4-dihydrocoumarin, $276 \mathrm{~nm}$ for coumarin and 2-hydroxycinnamic acid (o-coumaric acid) (Figure 1). The content of the determined compounds was calculated in $\mathrm{mg} 100 \mathrm{~g}^{-1}$ of dry matter (DM).

\section{Statistical analysis}

The results were analyzed using Statistica Plus software (StatSoft, Tulsa, USA). The mean values were compared by using One-way analysis of variance (ANOVA) followed by Tukey's multiple range test at $\alpha=0.05$ significance level and expressed as mean \pm standard deviation (SD). The differences between individual means were deemed to be significant at $\mathrm{P}<0.05$ and were marked as different letters in column rows. 
TABLE 3. Validation parameters of the HPLC-DAD analysis $(n=6)$.

\begin{tabular}{lccccccc} 
Compound & $t_{R}$ & $\begin{array}{c}\text { Precision } \\
(\mathrm{CV})\end{array}$ & Regression equation & $\begin{array}{c}\text { Linearity } \\
\left(\mathrm{r}^{2}\right)\end{array}$ & $\begin{array}{c}\text { Range } \\
(\mu \mathrm{gL} \mathrm{m}-1)\end{array}$ & $\begin{array}{c}\text { LOD } \\
\left(\mu \mathrm{mL}^{-1}\right)\end{array}$ & $\begin{array}{c}\text { LOQ } \\
\left(\mu \mathrm{mL}^{-1}\right)\end{array}$ \\
\hline 3,4-dihydrocoumarin & 5.10 & 0.57 & $\mathrm{y}=1282.2 \mathrm{x}-1038,4$ & 0.999 & $0.38-126.67$ & 0.033 & 0.110 \\
o-coumaric acid & 5.51 & 0.87 & $\mathrm{y}=1502.8 \mathrm{x}-2734,8$ & 0.999 & $1.06-353.08$ & 0.030 & 0.100 \\
Coumarin & 6.11 & 0.70 & $\mathrm{y}=14086.0 \mathrm{x}-7812,5$ & 0.999 & $0.40-133.20$ & 0.003 & 0.010 \\
\hline
\end{tabular}

$t_{R-}$ Retention time.

TABLE 4. Influence of shade on selected developmental traits of Southern sweet-grass (Hierochloë australis).

\begin{tabular}{lccc}
\hline \multirow{2}{*}{ Investigated parameters } & \multicolumn{3}{c}{ Shade level (mean \pm SD) } \\
\cline { 2 - 4 } & $0 \%$ & $35 \%$ & $50 \%$ \\
\hline Number of fertile shoots per plant & $121.9 \pm 17.0 \mathrm{a}$ & $139.3 \pm 15.9 \mathrm{a}$ & $82.6 \pm 12.1 \mathrm{~b}$ \\
Fertile shoots length (cm) & $51.6 \pm 6.2 \mathrm{~b}$ & $59.9 \pm 5.6 \mathrm{a}$ & $57.6 \pm 6.0 \mathrm{ab}$ \\
Weight of seeds per plant (g) & $1.01 \pm 0.06 \mathrm{c}$ & $1.14 \pm 0.06 \mathrm{~b}$ & $1.23 \pm 0.04 \mathrm{a}$ \\
1,000 seed weight (g) & $0.9540 \pm 0.0177 \mathrm{c}$ & $1.1186 \pm 0.0163 \mathrm{a}$ & $1.1590 \pm 0.0221 \mathrm{~b}$ \\
\hline
\end{tabular}

The different letters in rows indicate significant differences at $\mathrm{P}<0.05$.

TABLE 5. Influence of shade on selected leaf parameters of Southern sweet-grass (Hierochloë australis).

\begin{tabular}{|c|c|c|c|c|}
\hline \multirow{2}{*}{ Investigated parameters } & \multirow{2}{*}{$\begin{array}{l}\text { Stage of development/ } \\
\text { term of harvest }\end{array}$} & \multicolumn{3}{|c|}{ Shade level } \\
\hline & & $0 \%$ & $35 \%$ & $50 \%$ \\
\hline \multirow[t]{2}{*}{ Leaf number per plant } & $1^{\text {st }}$ cut & $132.20 \pm 34.63 a$ & $113.00 \pm 28.30 \mathrm{ab}$ & $90.80 \pm 28.22 b$ \\
\hline & $2^{\text {nd }}$ cut (regrowth) & $209.22 \pm 50.33 a$ & $240.33 \pm 61.03 a$ & $233.00 \pm 55.14 a$ \\
\hline \multirow[t]{2}{*}{ Leaf length $(\mathrm{cm})$} & $1^{\text {st }}$ cut & $32.30 \pm 7.57 \mathrm{~b}$ & $38.22 \pm 8.58 \mathrm{ab}$ & $45.36 \pm 9.10 a$ \\
\hline & $2^{\text {nd }}$ cut (regrowth) & $21.27 \pm 4.51 b$ & $27.05 \pm 5.30 \mathrm{a}$ & $28.48 \pm 5.24 a$ \\
\hline \multirow[t]{2}{*}{ Leaf width $(\mathrm{cm})$} & $1^{\text {st }}$ cut & $0.99 \pm 0.10 \mathrm{ab}$ & $1.07 \pm 0.12 a$ & $0.89 \pm 0.07 b$ \\
\hline & $2^{\text {nd }}$ cut (regrowth) & $0.85 \pm 0.09 a b$ & $0.92 \pm 0.11 a$ & $0.77 \pm 0.08 b$ \\
\hline \multirow{3}{*}{$\begin{array}{l}\text { Air dry weight of leaves } \\
\text { (g plant }^{-1} \text { ) }\end{array}$} & $1^{\text {st }}$ cut & $7.09 \pm 3.11 b$ & $12.44 \pm 3.05 a$ & $9.22 \pm 2.97 a b$ \\
\hline & $2^{\text {nd }}$ cut (regrowth) & $9.65 \pm 3.52 b$ & $21.19 \pm 5.26 \mathrm{a}$ & $16.58 \pm 4.36 \mathrm{a}$ \\
\hline & Cumulative weight & $16.74 \mathrm{c}$ & $33.63 a$ & $25.80 \mathrm{~b}$ \\
\hline
\end{tabular}

The values represent the mean $\pm S D$, and different letters in rows indicate significant differences.

TABLE 6. Influence of shade on chlorophyll $a$ and $b$, phenolic acids and coumarin compounds content in the leaves of Southern sweet-grass (Hierochloë australis).

\begin{tabular}{|c|c|c|c|c|}
\hline \multirow{2}{*}{ Investigated parameters } & \multirow{2}{*}{ Harvest } & \multicolumn{3}{|c|}{ Shade level } \\
\hline & & $0 \%$ & $35 \%$ & $50 \%$ \\
\hline \multirow{2}{*}{$\begin{array}{l}\text { Chlorophyll a content } \\
\left(\mu g^{-1} \mathrm{DM}\right)\end{array}$} & $1^{\text {st }}$ cut & $0.38 \pm 0.03 c$ & $0.79 \pm 0.02 b$ & $1.27 \pm 0.04 a$ \\
\hline & $2^{\text {nd }}$ cut (regrowth) & $0.30 \pm 0.04 c$ & $0.71 \pm 0.05 b$ & $1.09 \pm 0.05 a$ \\
\hline \multirow{2}{*}{$\begin{array}{l}\text { Chlorophyll } b \text { content } \\
\left(\mu g^{-1} \mathrm{DM}\right)\end{array}$} & $1^{\text {st }}$ cut & $0.14 \pm 0.02 c$ & $0.34 \pm 0.02 b$ & $0.56 \pm 0.04 a$ \\
\hline & $2^{\text {nd }}$ cut (regrowth) & $0.10 \pm 0.01 \mathrm{c}$ & $0.25 \pm 0.03 b$ & $0.39 \pm 0.01 a$ \\
\hline \multirow{2}{*}{$\begin{array}{l}\text { Chlorophyll } a+b \text { content } \\
\left(\mu g^{-1} \mathrm{DM}\right)\end{array}$} & $1^{\text {st }}$ cut & $0.52 \pm 0.03 c$ & $1.13 \pm 0.04 b$ & $1.83 \pm 0.06 a$ \\
\hline & $2^{\text {nd }}$ cut (regrowth) & $0.40 \pm 0.03 c$ & $0.96 \pm 0.06 \mathrm{~b}$ & $1.58 \pm 0.07 a$ \\
\hline \multirow[t]{2}{*}{ Chlorophyll a/b } & $1^{\text {st }}$ cut & $2.71 \pm 0.04 a$ & $2.32 \pm 0.08 b$ & $2.27 \pm 0.07 \mathrm{~b}$ \\
\hline & $2^{\text {nd }}$ cut (regrowth) & $3.00 \pm 0.04 a$ & $2.84 \pm 0.06 b$ & $2.79 \pm 0.06 \mathrm{~b}$ \\
\hline \multirow[t]{2}{*}{ Total phenolic acids content (\%) } & 1st cut & $0.45 \pm 0.04 a$ & $0.35 \pm 0.03 b$ & $0.26 \pm 0.04 c$ \\
\hline & $2^{\text {nd }}$ cut (regrowth) & $0.46 \pm 0.06 \mathrm{~b}$ & $0.58 \pm 0.07 a$ & $0.54 \pm 0.07 a$ \\
\hline \multirow{2}{*}{$\begin{array}{l}\text { Coumarin content } \\
\left.\text { (mg } 100 \mathrm{~g}^{-1} \mathrm{DM}\right)\end{array}$} & $1^{\text {st }}$ cut & $65.97 \pm 1.32 b$ & $67.08 \pm 1.45 b$ & $90.97 \pm 2.39 a$ \\
\hline & $2^{\text {nd }}$ cut (regrowth) & $40.98 \pm 1.05 b$ & $83.47 \pm 2.04 a$ & $91.29 \pm 2.16 \mathrm{a}$ \\
\hline \multirow{2}{*}{$\begin{array}{l}\text { 3,4-dihydrocoumarin content } \\
\text { (mg } 100 \mathrm{~g}^{-1} \mathrm{DM} \text { ) }\end{array}$} & $1^{\text {st }}$ cut & $54.80 \pm 1.27 a$ & $27.84 \pm 2.15 b$ & $14.08 \pm 0.87 \mathrm{c}$ \\
\hline & $2^{\text {nd }}$ cut (regrowth) & $38.63 \pm 1.81 \mathrm{a}$ & $27.35 \pm 1.37 \mathrm{~b}$ & $26.94 \pm 1.23 b$ \\
\hline \multirow{2}{*}{$\begin{array}{l}\text { o-coumaric acid content } \\
\text { (mg } 100 \mathrm{~g}^{-1} \mathrm{DM} \text { ) }\end{array}$} & $1^{\text {st }}$ cut & $15.04 \pm 1.33 a$ & $12.89 \pm 1.12 \mathrm{a}$ & $12.67 \pm 0.97 a$ \\
\hline & $2^{\text {nd }}$ cut (regrowth) & $17.51 \pm 1.64 a$ & $14.25 \pm 1.58 \mathrm{ab}$ & $12.14 \pm 1.77 \mathrm{~b}$ \\
\hline
\end{tabular}

The values represent the mean $\pm S D$, and different letters in rows indicate significant differences. 


\section{Results}

Plants cultivated in full sunlight and at 35\% shading produced a distinctly higher number of fertile shoots than those from $50 \%$ shade. The shoots of plants grown in full sunlight were the shortest. In turn, plants from $50 \%$ shade produced the highest mass of seed per plant. Moreover, their 1,000 seed weight was the highest. Plants cultivated in full sunlight were characterised by the lowest mass of seeds per plant and the lowest 1,000 seed weight (Table 4).

In the first harvest, the highest number of leaves was produced by plants cultivated in full sunlight. In the second harvest there was no significant differences concerning this trait. Plants grown at $50 \%$ shading produced the longest and the narrowest leaves, irrespective of the date of harvest. The highest cumulative weight of leaves (from two cuts) was obtained at $35 \%$ shading. Plants grown in full sunlight were characterised by the lowest mass of raw material in both harvest terms (Table 5).

The highest content of chlorophyll $a$ and $b$ was observed in plants grown at $50 \%$ shading and the lowest - in full sunlight. The value of chlorophyll $a$ to $b$ ratio was reduced in shade conditions mainly due to greater increase of chlorophyll $b$ than chlorophyll $a$. Total phenolic acids as well as coumarin compounds contents were strictly related with the shade level and term of harvest, as well. In the first cut, the content of phenolic acids was the highest in full sunlight, and the lowest at $50 \%$ shade. In the second cut plants from full sunlight were characterized with lower content of those substances, compared to 35 and $50 \%$ shading.

In the summer ( $1^{\text {st }}$ cut) higher content of coumarin was observed in plants cultivated under $50 \%$ shading $(90.97$ mg $100 \mathrm{~g}^{-1} \mathrm{DM}$ ), in comparison with full sunlight and 35\%

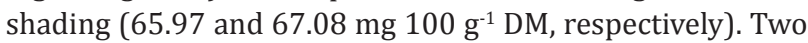
months later, during autumn ( $2^{\text {nd }}$ cut $)$ the content of this compound was significantly higher in plants grown at 35 and $50 \%$ shading (83.47 and $91.29 \mathrm{mg} 100 \mathrm{~g}^{-1} \mathrm{DM}$, respectively), compared to those from full sunlight (40.98 mg $100 \mathrm{~g}^{-1} \mathrm{DM}$ ). In contrary to coumarin, the content of 3,4-dihydrocoumarin and o-coumaric acid was the highest in plants grown in full sunlight (Table 6).

\section{Discussion}

Shade is a common tool used in plant cultivation, especially in the tropical regions of the world with very high sun irradiation rates. It may be also useful in temperate climate as an important agronomic factor improving plant productivity (Fini et al., 2010). Plant responses to shade include a variety of developmental and biochemical adaptations influencing both the yield or raw materials and accumulation of biologically active compounds (Peralta et al., 2002; Chang et al., 2008). Presented results show that southern sweet-grass, wild growing species much adapted to reduced light levels, in cultivation strongly responds to shade. Significant differences, between plants grown in full sunlight and those cultivated at 35 and 50\% shading were observed concerning both generative and vegetative development (Tables 3 and 4). The information on generative development of southern sweet-grass are very scarce. In its natural habitat the plant starts flowering at the early spring. Just after seed setting, it begins vegetative growth. The seed material of the plant are spikelet (commonly called seeds), consisting of one caryopsis. According to our results, shade seems to be the most appropriate in terms of southern sweet-grass generative development. Plants cultivated at $50 \%$ shading produced the highest mass of seeds per plant and the highest 1,000 seed weight. In turn, plants grown in full sunlight produced the lowest mass of seeds per plant and the lowest 1,000 seed weight (Table 4).

The industrial raw material collected from southern sweet-grass are leaves. From wild growing plants they are harvested two- or even three times during vegetation period. Improper collection technique is considered to be a main reason for regression of the species in its habitat. According to Bączek et al. (2015), the weight of southern sweet-grass leaves collected from the wild is very diversified, and ranges between 1.54 to $11.07 \mathrm{~g}$ per plant. The most important yielding parameters of the species are the length and width of leaves as well as their number per plant. Our results show that those parameters are strictly combined with the shade level. Generally, steppe grasses grown naturally in full sunlight produce more biomass, tillers and leaves, than plants grown in shade (Pierson et al., 1990). In our experiment, in the first cut, southern sweet-grass grown in full sunlight produced a distinctly higher number of leaves. However, they were considerably shorter than those of plants cultivated under shading nets, and in consequence their weight was the lowest. The longest and the narrowest leaves were produced by plants grown at 50\% shading (Table 5). According to Podyma et al. (2010), deep shade (70\%) strongly reduces southern sweet-grass growth and the mass of its leaves. However, in our experiment due to a significant increase in the leaves number in September $\left(2^{\text {nd }}\right.$ cut $)$, the highest cumulative weight of leaves was obtained from plants cultivated at $35 \%$ shading (Table 5).

Southern sweet-grass is a typical understory plant. Photosynthetic acclimation is crucial to the survival of such species (Chazdon, 1988). According to many authors low light intensity may stimulate photosynthetic pigments concentration (Czeczuga, 1987; Yang et al., 2007; Fini et al., 2010). It was observed in our study, as well. Chlorophyll $a$ and $b$ as well as $a+b$ content increased in shaded plants, and the highest rate of chlorophyll $b$ was observed at its maximum while chlorophyll $a / b$ rate was the lowest (Table 6). Such phenomena, described also in the studies of some forest trees like Fagus sylvatica L., Abies alba L., Acer pseudoplatanus L. (Lichtenthaler et al., 2007) may confirm that southern sweet grass is a typical forest, shade-loving plant. According to Ryser and Eak (2000), light plasticity of different plant species contributes to their ability to occupy diverse habitats. Thus, plants characterized with a narrow range of light requirements are more vulnerable to environmental changes and more endangered. This may be also a reason why southern sweet-grass has become very rare in its natural habitat.

One of the most important groups of biologically active compounds identified in southern sweet-grass leaves are phenolics. Among them chlorogenic, ferulic, caffeic acids as well as some flavonoids were reported by Podyma et al. (2010), and Przybył et al. (2011). The synthesis of phenolic compounds, i.e., hydroxycinnamic acids, flavonoids or tannins, depends on leaf carbon economy and may be induced by biotic and abiotic stress. They serve multiple functions, beginning with chemical defence against herbivores and pathogens, protection against ultraviolet and oxidative stress. They are also used as chemical communication signals (Meyer et al., 2006; Karimi et al., 2013). High total phenolic acid content in southern sweet-grass cultivated in full sunlight may be therefore related with the protection of a photosynthetic apparatus of a plant naturally adopted to shade, against high irradiation (Table 6). 
The industrial quality of southern sweet-grass leaves depends mostly on the coumarin compounds content, with coumarin as a dominant. Coumarin is responsible for specific sweet, cherry-like odour of the raw material. According to Stallknecht and Fornsworth (1982), coumarins are considered as plant hormones of a wide range of actions. During plant senescence they prevent plants from the loss of chlorophyll and in consequence they delay the process. The effect of shade on coumarin content was previously observed by De Castro et al. (2006) and Bertolucci et al. (2013) on Brazilian species Mikania glomerata Spreng. (Asteraceae), popularly known as 'guaco', growing naturally in South American forests. In the leaves of cultivated guaco, the content of coumarin reached its peak in deep shade (Bertolucci et al., 2013). In our investigation on southern sweet-grass a similar tendency was observed. Plants cultivated at 50\% shade were characterised with the highest content of coumarin compared to $35 \%$ shade and full sunlight (Table 6).

Our results show that southern sweet-grass grown at moderate shade $(35 \%)$ produces high yield of leaves, whereas deeper shade stimulates accumulation of coumarin, responsible for their quality. The reproductive ability of the species is also combined with shade level. Deeper shade $(50 \%)$ seems to be more favourable to generative development of southern sweet-grass. The highest mass of seeds per plant and the highest 1,000 seed weight, were obtained at $50 \%$ shading.

Given the results obtained in the present study, in cultivation of southern sweet-grass it is recommended to limit sunlight during the vegetation season. It seems that the best light condition is a moderate shade (35\%), providing the highest yield of raw material (leaves) rich in coumarin.

\section{Acknowledgments}

The work was supported by National Science Centre, project No. N N310 728440.

\section{References}

Bączek, K., Angielczyk, M., Mosakowska, K., Kosakowska, O., and Węglarz, Z. (2014). Setting of southern sweet-grass plantation with stem cuttings obtained by division of maternal plants. Herba Pol. 60(4), 9-21. https://doi.org/10.1515/hepo-2015-0001.

Bączek, K., Angielczyk, M., Przybył, J.L., Ejdys, M., Geszprych, A., and Węglarz, Z. (2014). Functional traits of selected clones of southern sweet-grass (Hierochloë australis/ Schrad./ Roem. \& Schult.). Herba Pol. 60(3), 23-33. https://doi.org/10.2478/hepo-2014-0013.

Bączek, K., Angielczyk, M., Przybył, J.L., Kosakowska, O., Ejdys, M., and Węglarz, Z. (2015). Variability of southern sweet-grass (Hierochloë australis/ Schrad./ Roem. \& Schult.) wild growing populations occurring in eastern Poland. Herba Pol. 61(3), 23-36. https://doi. org/10.1515/hepo-2015-0020.

Bertolucci, S.K., Pereira, A.B.D., Pinto, J.E.B.P., Oliveira, A.B., and Braga, F.C. (2013). Seasonal variation on the contents of coumarin and kaurane-type diterpenes in Mikania laevigata and M. glomerata leaves under different shade levels. Chem. Biodivers. 10, 288-295. https://doi.org/10.1002/cbdv.201200166.

Chang, X., Alderson, P.G., and Wright, C.J. (2008). Solar irradiance level alters the growth of basil (Ocimum basilicum L.) and its content of volatile oils. Environ. Exp. Bot. 63, 216-223. https://doi. org/10.1016/j.envexpbot.2007.10.017.

Chazdon, R.L. (1988). Sunflecks and their importance to forest understory plants. Adv. Plant Physiol. 28, 355-377.
ChromaDex's Tech Tip 0003: Reference Standard Recovery and Dilution and used as standard stock solutions. https://www.chromadex.com/media/2126/techtip0003recoverydilutionprocedures_nl_pw.pdf.

Ćwikliński, E., and Głowacki, Z. (1990). Nowe stanowiska rzadszych gatunków w dolinie dolnego Bugu. Zesz. Nauk. Wyższ. Szk. Roln.-Ped. w Siedlcach, Nauk. Przyr. 19, 121-124.

Czeczuga, B. (1987). Carotenoid contents in leaves grown under various light intensities. Biochem. Syst. Ecol. 15, 523-527. https:// doi.org/10.1016/0305-1978(87)90098-6.

De Castro, E.M., Pinto, J.E.B.P., Bertolucci, S.K.V., Malta, M.R., Cardoso, M.G., and Silva, F.A.M. (2006). Coumarin content in young Mikania glomerata plants (Guaco) under different radiation levels and photoperiod. Acta Farm. Bonaerense 25(3), 387-392.

Fini, A., Ferrini, F., Frangi, P., Amoroso, G., and Giordano, C. (2010). Growth, leaf gas exchange and leaf anatomy of tree ornamental shrubs grown under different light intensities. Eur. J. Hortic. Sci. 75(3), 111-117.

Gawłowska, J., Sulma, T., and Wierzchowska-Renke, K. (1989). Turówka wonna (Hierochloë odorata) i turówka leśna (Hierochloë australis) - zasoby i zagrożenia. Chrońmy Przyr. Ojcz. 5(6), 60-69.

ISTA (2014). International Rules for Seed Testing. International Seed Testing Association.

Karimi, E., Jaafar, H.Z.E., Ghasemzadeh, A., and Ibrahim, M.H. (2013). Light intensity effects on production and antioxidant activity of flavonoids and phenolic compounds in leaves, stems and roots of three varieties of Labisia pumila Benth. Aust. J. Crop Sci. 7(7), 10161023.

Lake, B.G. (1999). Coumarin metabolism, toxicity and carcinogenicity: relevance for human risk assessment. Food Chem. Toxicol. 37(4), 423-453. https://doi.org/10.1016/S0278-6915(99)00010-1.

Lichtenthaler, H.K., and Wellburn, A.R. (1983). Determination of total carotenoids and chlorophylls $a$ and $b$ of leaf extracts in different solvent. Biochem. Soc. Trans. 11, 591-592. https://doi.org/10.1042/ bst0110591.

Lichtenthaler, H.K., Ac, A., Marek, M.V., Kalina, J., and Urban, 0. (2007). Differences in pigment composition, photosynthetic rates and chlorophyll fluorescence images of sun and shade levels of four tree species. Plant Physiol. Biochem. 45, 577-588. https://doi. org/10.1016/j.plaphy.2007.04.006.

Meyer, S., Cerovic, Z.G., Goulas, Y., Montpied, P., Demotes-Mainard, S., Bidel, P.R., Moya, I., and Dreyer, E. (2006). Relationship between optically assessed polyphenols and chlorophyll contents, and leaf mass per area ratio in woody plants: a signature of the carbonnitrogen balance within leaves? Plant Cell and Environ. 29, 13381348. https://doi.org/10.1111/j.1365-3040.2006.01514.x.

Mirek, Z., Zarzycki, K., Wojewoda, W., and Szeląg, Z. (2006). Red List of Plants and Fungi in Poland. (Krakow: W. Szafer Institute of Botany, Polish Academy of Science).

Peralta, G., Perez-Loorens, J.L., Hernandez, I., and Vergara, J.J. (2002). Effects of light availability on growth, architecture and nutrient content of the seagrass Zostera noltii Hornem. J. Exp. Mar. Biol. Ecol. 269, 9-26. https://doi.org/10.1016/S0022-0981(01)00393-8.

Pierson, E.A., Mack, R.N., and Black, R.A. (1990). The effect of shading on photosynthesis, growth, and regrowth following defoliation for Bromus tectorum. Oecol. 84, 534-543. https://doi.org/10.1007/ BF00328171.

Podyma, W., Bączek, K., Angielczyk, M., Przybył, J.L., and Węglarz, Z. (2010). The influence of shading on the yield and quality of southern sweet-grass (Hierochloë australis (Schrad.) Roem. et Schult.) raw material. Herba Pol. 56, 14-19. 
Polish Pharmacopoeia VIII. (2008). Polskie Towarzystwo Farmaceutyczne. Warszawa.

Przybył, J.L., Paczesna, E., Angielczyk, M., Bączek, K., Podyma, W., Geszprych, A., and Weglarz, Z. (2011). Intraspecific variability of southern sweet-grass (Hierochloë australis (Schrad.) Roem. et Schult.) wild growing in Poland. Acta Hortic. 925, 89-95. https://doi. org/10.17660/ActaHortic.2011.925.11.

Radusciene, J. (2002). Report of a Working Group on Medicinal and Aromatic Plants, E. Lipmann, ed. European Cooperative Programme for Plant Genetic Resources. Biodiversity International.

Ryser, P., and Eek, L. (2000). Consequences of phenotypic plasticity vs. intraspecific differences in leaf and root traits for acquisition of aboveground and belowground resources. Am. J. Bot. 87, 402-411. https://doi.org/10.2307/2656636.

Stallknecht, G.F., and Farnsworth, S. (1982). General characteristics of coumarin induced tuberization of axillary shoots of Solanum tuberosum cultivated in vitro. Am. Potato J. 59(1), 17-32. https://doi. org/10.1007/BF02854880.

Węglarz, Z., Geszprych, A., Angielczyk, M., and Pawełczak, A. (2004). Wstępne badania nad plonowaniem i wewnątrzgatunkową zmiennością chemiczną turówki leśnej (Hierochloë australis (Schrad.) Roem. et Schult.). Zesz. Probl. Post. Nauk Roln. 497, 621626.

Wierzchowska-Renke, K. (1993). Wpływ nawożenia wybranymi pierwiastkami na sezonową zawartość kumaryny i niektórych makro - i mikroelementów w zielu Hierochloë australis. Ann. Acad. Med. Gedan. 23, 27-35.

Yang, X.Y., Ye, X.F., Liu, G.S., Wei, H.Q., and Wang, Y. (2007). Effects of light intensity on morphological and physiological characteristics of tobacco seedlings. Chin. J. Appl. Ecol. 18, 2642-2645.

Received: Apr. 28, 2017

Accepted: Dec. 8, 2017

Addresses of authors:

Katarzyna Bączek*, Jarosław L. Przybył, Olga Kosakowska and Zenon Węglarz

Laboratory of New Herbal Products, Department of Vegetable and Medicinal Plants, Faculty of Horticulture, Biotechnology and Landscape Architecture, Warsaw University of Life Sciences - SGGW, Nowoursynowska 166, 02-787 Warsaw, Poland

*Corresponding author; E-mail: katarzyna_baczek@sggw.pl 